\title{
TURKEY'S SLOW REVOLUTION
}

\author{
Birol Baskan \\ The Middle East Institute
}

\begin{abstract}
If revolutions are such incidences of large-scale sudden changes in the composition of political elites as a result of spontaneous or organized mass mobilization, Turkey has undergone none. Turkey has somehow escaped a fate that befell on such countries in its neighborhood as Russia, Iran, or Egypt. Turkey has somehow managed to contain all radicalisms, whether of the Leftist or the religious kind and even transformed some, if not all, agents of radicalisms into the servants of the dominant political and economic system. Turkey has nurtured, however, a number of groups or movements that have pursued a revolutionary agenda. One of them, a religious kind, has pursued an unusual strategy. Generally referred as the Gülen movement, this religious group, or simply the Cemaat, has pursued an agenda that is revolutionary because it has aimed at an almost total transformation of the state and the society. The group's strategy is unusual, however, in that it necessitated extreme temporal patience, or years of hard work.
\end{abstract}

Keywords: Erdoğan, Gülen, Said Nursi, Messianism, Islam, revolution.

If revolutions are such incidences of large-scale sudden changes in the composition of political elites as a result of spontaneous or organized mass mobilization, Turkey has undergone none. Turkey has somehow escaped a fate that befell on such countries in its neighborhood as Russia, Iran, or Egypt. Turkey has somehow managed to contain all radicalisms, whether of the Leftist or the religious kind and even transformed most, if not all, agents of radicalisms into the servants of the dominant political and economic system. ${ }^{1}$

Even though Turkey has undergone no social revolution, it still witnessed a dramatic transformation of the character and composition of its political elite. This transformation was the work of many actors. But, one religious actor was particularly instrumental: what came to be generally known as the Gülen movement or the Cemaat. This paper argues that this movement pursued an unusual strategy to bring about the said transformation. It was unusual because the movement's strategy necessitated extreme temporal patience, or years of hard work. This article traces the movement's strategy back to the messianism of Said Nursi and discusses the conditions that led the movement to adopt such a strategy. In brief, we argue that the movement's leader, Fethullah Gülen, was relatively young and without any religious capital when he set out to found a new religious group.

As it stands now, however, the movement's future in Turkey is uncertain: it has lost almost all gains of its past activities and has been totally decimated in its home country especially after July 2016 . But, the movement has greatly helped the currently ruling Justice and Development Party (JDP) greatly pacify the old Kemalist guards in Turkey thus staging revolution hand in hand with the JDP. The eventual fate the movement met provides another illustration of revolutions' Saturn-like nature: they devour their own children.

This paper is about this religious group, the Cemaat, introducing first its messianic character and then its unusual strategy.

Journal of Globalization Studies, Vol. 10 No. 2, November 2019 91-100

DOI: $10.30884 / j o g s / 2019.02 .07$ 


\section{The Cemaat's Messianism}

The Cemaat originated in the 1960s, but its messianism can be traced back to Said Nursi, a man as eccentric as the group's founder and leader, Fethullah Gülen. Said Nursi was born in 1878 in Nurs, a village in the mountainous region south of Lake Van and passed away in 1960 in the south-eastern city of Urfa. ${ }^{2}$ He thus lived his formative years in the turbulent last decades of the Ottoman Empire, witnessing its collapse and the subsequent foundation of the Republic in its stead. By the time Nursi reached adulthood the great power disparity between Europe and the Islamic world was no longer a matter of dispute: Europe was definitely the superior and the Islamic world definitely the inferior. More importantly, this disparity had already created a hostile international environment for the Muslim world. Major international powers were blatantly aggressive and had already colonized a good part of it.

In this life and death battle of survival the Ottoman statesmen had been reforming the Ottoman state at least since the early nineteenth century, building a European-style army, educational and legal system and centralizing its administration. Whatever we call it, modernization, state building, westernization, the whole process was also transforming religion or, to be more specific, noticeably restricting its public role in the Empire. The Republic would go even further than the Ottoman Empire and implemented a series of reforms, all in an effort to carve an even more restricted space for religion in public life, reforms ranging from the abolition of the caliphate to the closure of religious seminaries, religious courts, to closure of Sufi orders. ${ }^{3}$

Said Nursi became the man he was in this context. He was born into a Kurdish peasant family with no prominent religious figure among its ranks: yet, his father also served as a local imam who steered his children towards religious education. Said had in fact pursued a quite irregular religious education in different madrasahs of the Kurdish region, finally obtaining his diploma in 1892. After graduation, Said travelled in different cities of the Kurdish region and first settled in Bitlis in 1895 and then in Van in 1895. In both cities, where he had stayed for a total of 12 years, Said Nursi further expanded his knowledge of religious sciences and, more importantly, familiarized himself with natural sciences.

During his stay in Bitlis and Van, Said Nursi also became familiar with the major political and intellectual problems of the period. It was probably in this period that Said Nursi developed this powerful feeling that the very existence of Islam was under threat. Yet, that feeling had intensified, reaching the level of paranoia, only after Said Nursi met with Mustafa Kemal in Ankara in 1922. If Said Nursi's recollections are to be trusted, he would say about what he sensed in Ankara:

I went to Ankara in 1922. I saw that a powerful current of atheism was treacherously working to enter, corrupt, and poison the strong minds of the faithful... I said, 'this monster is going to damage the fundamentals of belief'... I wrote a strong proof derived from the Qur'an powerful enough to destroy the head of that atheism in an Arabic treatise of light. I got it published in Ankara at the Yeni Gün Press. But, unfortunately, because those who knew Arabic were few and those who took the treatise seriously were rare, that extremely concise and abbreviated proof did not have its effect and sadly, the current of atheism both developed and gained strength. ${ }^{4}$

Deeply disappointed Said Nursi left Ankara and settled in Van. Three years later a massive Kurdish rebellion broke out. Even though Said Nursi refused to join the rebel- 
lion, he was exiled to a small village, Barla, in south central Anatolia. Nursi would spend the rest of his life under the watchful eyes of the Republic in different Anatolian towns.

Having gone through enormous personal hardships during the one-party period, Said Nursi's view of the new regime could not be positive. His view of Mustafa Kemal was particularly harsh. Nursi's view of him can be most clearly seen in a treatise called 5 . Şua (5th Ray) in Şualar (the Rays), in which Said Nursi interpreted the Prophetic traditions, known as hadiths, describing the signs of the end of time: in his interpretations Nursi portrayed Mustafa Kemal Atatürk as the Sufyan, the anti-christ who would emerge among Muslims. Even though Said Nursi did not specifically name, his interpretations of the hadiths obviously point to Mustafa Kemal Atatürk. For example, he interpreted the hadith which prophesizes, 'the formidable man of the end of time will wake up one morning and will find "this is infidel (kafir)" written on his forehead' in the following way: '.. an interpretation of this might be: "that Sufyan will put the foreigners' hat on his own head and will force all others wear it as well," obviously referring to Atatürk's hat reform. Likewise, Said Nursi interpreted the hadith which prophesizes, 'towards the end of time, there will be no one who will utter Allah Allah,' with reference to the closure of madrasahs (higher religious schools) in 1924 and sufi dervish lodges in 1925, and the translation of the islamic call to prayer, known as ezan, into Turkish.

Said Nursi had no other option, but to devote himself fully to religious scholarship. In Barla he set out to pen what became Risale-i Nur, a gigantic collection of religious treaties. ${ }^{5}$ Said Nursi had in fact been working on the project at least since his publication in 1911 of Muhakemat (Reasonings) in which Said Nursi basically argued that Islam's Holy Book, the Qur'an, and modern sciences did not conflict. During his stay in Istanbul during the Independence War (1919-1922), he published several other works. During the Republic, Said Nursi simply expanded the main points of these earlier works, making them more understandable to the masses by extensively employing illustrative allegories.

This is critical to note. Said Nursi saw himself on a religious mission, a mission that countered Mustafa Kemal Ataturk's Sufyanic-mission. And that mission had to be necessarily a mission only Mahdi, the awaited Christ-like figure of Islam, could undertake. Said Nursi never called himself the awaited Mahdi. For him the task of Mahdi was so monumental, no one person could have undertaken it. That mission required the shoulders of many forming a religious group. Said Nursi, however, claimed that writing Risale-i Nur, which would strengthen faith in God, was the first stage in the realization of that giant mission of Mahdi. The second stage, Said Nursi named 'hayat or life' would be to expand the circle of students who read and live up to Risale-i Nur so that Risale-i Nur would enter all walks of life through such students. Upon these two stages the awaited Mahdi would rise and complete the third and final stage: that is to establish the Islamic Shariah. ${ }^{6}$

Said Nursi did not live to see the second stage of his prophetic vision, a stage his students would enter all walks of life. By the time he passed away in 1960 his closelyknit community of disciples had not expanded much beyond a few hundreds and was active only in a few towns. ${ }^{7}$ If it has ever been realized and if any one person has to be credited for it, it should be Fethullah Gülen. Joined Said Nursi's movement in the mid-1950s in the eastern town of Erzurum, Gülen began to form his own group in the mid-1960s in the western town of Izmir.

Whatever differences set Fethullah Gülen apart from Said Nursi, the group has seen itself as a part of the broader movement initiated and inspired by Said Nursi. The Gülen group had until recently run a publishing house that printed Risale-i Nur and a books- 
tore that sold Risale-i Nur in its shelves. There are also reliable reports that the group members have regularly read Risale-i Nur in their meetings along with Fethullah Gülen's own writings. Given that neither Fethullah Gülen nor any of his disciples trained in religion has so far denied Said Nursi's claim to a messianic mission, it is not far-fetched idea that the group has seen itself in the same role.

There is, however, no question that the group helped Risale-i Nur enter all walks of life. In that sense the Gülen group indeed realized the second stage in Said Nursi's prophecy.

\section{The Cemaat's Long-Shot Strategy}

Like Said Nursi, Fethullah Gülen also adopted an unusually long-term strategy to realize whatever the mission he had in mind in the very beginning. This was not a matter of choice, but rather an imposition by the very simple fact that Fethullah Gülen was extremely young for an aspiring religious leader when he began to form his religious group in the western town of Izmir.

Gülen settled in that town in 1965. Born in 1941, Gülen was just 24 years old. Furthermore he could not lay claim to any other socio-religious capital: his father was an ordinary prayer leader in Korucuk, an obscure village in the province of Erzurum; no other family member was known to be a prominent religious figure; nor was he blessed by any Sufi Sheikh. He joined Said Nursi's movement, but was not in the leadership cadre.

Fortunately he was a preacher at the Directorate of Religious Affairs, so had a regular access to the masses through the pulpit. But, that was also a disadvantage. As Gülen was a state employee, he had to work within certain perimeters the Turkish state had set for preachers. He therefore had to focus on ritual perfection, extreme asceticism ${ }^{8}$ and ceaseless activism for what he called the service of Islam. ${ }^{9}$

Yet, he could not overcome the age disadvantage. In this early stage Gülen appealed to the youth only, more specifically secondary and high school students. Fortunately when Gülen came to Izmir, he also became an administrator at a dorm, where students of state-run religious vocational schools stayed. It was during his stay in this dorm that Gülen recruited his most loyal disciples, who later formed the leadership cadre of the movement.

Since then the Cemaat has actively worked to recruit new members among secondary and high school students. As it happened elsewhere in the Muslim world, the expansion of the public educational system, yet with gradual deterioration in quality, provided invaluable opportunities for the Cemaat. By offering free and private classes to secondary and high school students, the Cemaat could keep regular access to the pool of young recruits.

Having such a young body of followers, who were yet to make critical life decisions, the Cemaat elders (or abiler in Turkish), inadvertently perhaps, also came to play a role in helping them make those decisions. One obvious recommendation the Cemaat elders could give to their younger brothers/sisters was to find a job in the state institutions. In Turkey of the 1970s the group did not have much option either. The state was then, and still is to a certain extent, a major employer. Gülen was himself was a state employee.

Among all the state institutions, the Armed Forces and the Police were particularly attractive. Both institutions recruited its ranking officers in the tradition of the old Ottoman devshirme system when they were young. Yet, it is hard to assess the extent the Cemaat had benefitted from this recruitment system in the 1970s. Who would constitute the future leadership of the Cemaat seemed to have entered either Ministry of Education 
as teachers or the Directorate of Religious Affairs as prayer leaders and preachers. ${ }^{10}$ Whether any member of the Cemaat entered the military high schools in the 1970s, we simply do not know. But, some must have entered the Police High School. A few police chiefs who are jailed now as part of the ongoing investigation entered the Police High School in the 1970s. ${ }^{11} \mathrm{e}$ that in the highly politicized political environment of the $1970 \mathrm{~s}$, radicals of the right and of the left were more attractive for the age group Gülen could appeal. Despite Gülen's personal charisma and tireless efforts the Cemaat had not grown much in that crisis decade. ${ }^{12}$ The military coup in 1980 fundamentally changed this environment. Even though it brought personal hardships for Fethullah Gülen, who had been on the run for six years, ${ }^{13}$ it proved to be truly an auspicious event for the Cemaat.

The military unleashed a sweeping crackdown on both the Left and the Right and destroyed whatever network they had developed among the masses, especially among the high school and university students. The coup unintentionally perhaps emptied the space that the Cemaat filled in and exponentially increased its membership throughout the 1980s especially among university students. ${ }^{14}$ The Cemaat had also continued to recruit secondary and high school students as it had now acquired more institutional channels such as university preparation courses and private schools.

The military also initiated an economic liberalization program that eventually also helped the Cemaat, and other religious groups, for economic liberalization came to benefit a new class of businessmen and merchants independent of the state. Backed by this newly moneyed class like other religious groups the Cemaat expanded its activities into media, education and business. By the 1990s, the Cemaat had a newspaper, journals, a TV channel, radio stations, private schools, private housings and dormitories. It even opened its own interest-free bank, Asya Finans, later Bank Asya.

In the 1980s, the Cemaat had no apparent reason not to place its student-members in the state especially in the military and the police as it had an ever-expanding pool of them: the Cemaat encouraged those bright secondary school students into the schools that trained the officer corps of the military and the police.

The military proved to be much more immune to the Cemaat's efforts than the rest of the state institutions. The military had been more autonomous than the police and other state institutions from the political parties in government. Furthermore, the military systematically purged the members of the Cemaat from its schools and ranks. In the second half of the 1980s, for example, the military expelled tens of military students, claimed to have affiliation with the Cemaat (Göktaş, 1987). Since then the Armed Forces had systematically purged members of the Cemaat and other religious groups from its ranks well until 2010. Throughout the 1990s, for example, the High Military Council expelled more than 1,200 military officers, most of them on charge of engaging in 'backward activities' or 'irticai faaliyetler' in the military parlance (Anonymous, 2009, December 6).

The police had been much easier simply because unlike the military it had been fully under the civilian control. While a special council, the High Military Council, had basically been running the military in making the critical decisions of promotions and appointments, the Ministry of Interior had been running the police, making all appointments and promotions within the police. Facing an electoral competition, the politicians did not really want to upset the conservative voters and had therefore been more lenient towards the Cemaat's penetration into the police. ${ }^{15}$ Reflecting their leniency, for exam- 
ple, they ignored intelligence reports about the Cemaat's expanding influence within the police. $^{16}$

In the 1990s the Cemaat had continued to expand since then diverting more of its energy to spreading its educational activities in Africa, Latin America, and North America, in addition to East Europe, Central Asia and Far East Asia. Along with educational activities the group also helped its businessmen and merchant members to undertake ventures in these new places. The group's newspaper, Zaman, became the largest newspaper in Turkey, its circulation reaching at around 1,000,000 except in summers.

Throughout the 1980s and the 1990s the Cemaat had distanced itself from all political parties and very carefully kept an above-politics image. This was to change in the 2000s. It had given unprecedented support to the Justice and Development Party (JDP) that came to power in 2002. The strong man of the party, Recep Tayyip Erdogan, ${ }^{17}$ who was himself victim, like the Cemaat, of the Kemalist guards, must have seen in the Cemaat an ally. Even though Erdogan hailed from political Islam tradition, he seemed to have developed cordial relations with the Cemaat especially during his tenure as the mayor of Istanbul. Many other leading figures of the JDP had also cordial relations with the Cemaat. It was not surprising then that the JDP, once in power, would promote the Cemaat's cadres in the state.

New in power, the JDP had yet to consolidate its popularity among the masses. To this economic recovery was its wildcard for the 1990s were economically depressing years for many in Turkey. With the JDP, Turkey was back again on the path of continuous economic growth. Between 2002 and 2007, the Turkish economy grew from 232.7 billion to 657 billion in current US dollars. In the same period, per capita Gross National Income increased from $3,250 \$$ to $8,020 \$ .^{18}$ As a result of this economic success, the party won a landslide victory in the 2007 national elections, increasing its vote share by 11 per cent since the 2002 elections, an increase hitherto unheard of in Turkish politics.

More confident now, JDP could directly aim at taming its most stubborn enemy, the Kemalist establishment in the higher echelons of the military, the judiciary, universities and the media. In this task the JDP found the Cemaat's cadres in the state as its natural allies. The notorious Ergenekon and Balyoz investigations would be the fruits of this JDP-Cemaat alliance. ${ }^{19}$ Both investigations charged that certain high-ranking military officers in the Armed Forces, in cooperation with a number of university professors, police chiefs, journalists, academics and businessmen, had conspired against the democratically elected government of Turkey. ${ }^{20}$ As part of the investigations such figures as, Ilker Basbug, former Chief of Staff, Mehmet Sener Eruygur, former Chief of Military Police, Ahmet Hursit Tolon, former Chief of the First Army, Halil Ibrahim Firtina, former Chief of the Air Forces, Ozden Ornek, former chief of the Navy, and Cetin Dogan, former Chief of the First Army and many other lower-ranking military officers were implicated and even put in jail.

In retrospect, what happened in Turkey then was really a within-state struggle, one group marginalizing and purging another with the strong support from the JDP government. It was because no group other than the Cemaat could mobilize such a broad cross-institutional coalition within the state, it was most likely that the Cemaat's cadres in the state pursued and brought to a conclusion both the Ergenekon and Balyoz investigations. It is certain, however, that that the Cemaat's own media cheerfully joined the broader media chorus and helped the formation of a very strong public opinion in favor of the investigations. 
The Ergenekon and Balyoz investigations totally demoralized the Turkish Armed Forces and forced it into a period of political silence and acquiesce, a period that has lasted to this day. Still though largely autonomous the High Council of Military would be making appointments and promotions in years to come. The number of military officers expelled from the Armed Forces on charges of regressive activities had already been declining from 44 military officers in 2002 to 15 in 2005. In 2006-2009 the High Council expelled a total of 24 military officers only and none from 2010 to 2015.

The military retreated back to their barracks and the Kemalists totally demoralized, the JDP-Cemaat alliance targeted the High Council of Judges and State Prosecutors. The September 2010 referendum, passed thanks to the popularity of the JDP, changed the procedures of the formation of this council and the Constitutional Court. With the new procedures, thousands of judges and state prosecutors would elect half of the members of the Council and therefore have the overwhelming voice in the formation of the High Council of Judges and State Prosecutors. The referendum in fact opened the doors for a radical overhaul of the high echelons of the judiciary in Turkey.

A superficial comparison between the last members of the Council elected according to the pre-referendum procedures and the first members elected according to the post-referendum procedures will be illustrative. Before the referendum, the High council consisted of seven regular and five substitute members, two of the regular members being the Minister of Justice and his undersecretary. Looking at the professional careers of the ten regular members, excluding the Minister and his undersecretary, the road to the High Council had passed through Court of Cassation and Council of State: all members of the High Council had previously worked in these two judicial institutions. For example, among the regular members, Kadir Ozbek had worked in the Court of Cassation since 2001; Suna Turkoglu in Council of State since 1978, Musa Tekin in Court of Cassation in Court of Cassattion since 2003, Orhan C. Erbuk in Council of State since 1978, and Ali S. Ertosun in Court of Cassation since 2003. Moreover, all ten members of the Council had a degree in law: eight of them from Ankara University and two of them from Istanbul University. ${ }^{21}$

Consisting of 22 regular and 12 substitute members, the new members of the High Council, on the other hand, represent a broader sector of the Judiciary for half of them are elected by their peers. Looking at the professional careers of the 22 regular and 12 substitute members of the High Council, work experience in the Court of Cassation and the Council of State does not appear to be the only road to membership in the High Council: the new members of the High Council have a much diverse professional and educational background. ${ }^{22}$ Having members across the judicial system and able to mobilize them, the Cemaat must have benefitted from the procedural changes introduced in the 2010 referendum.

It was just a matter of time that the JDP and the Cemaat would hand in hand complete the revolution they started. The next three years were the Cemaat's golden years in Turkey, expanding its presence in the state and placing his members in high state bureaucracy.

But, this period also saw the first cracks in the relationship: in February 2012, an Istanbul State Prosecutor invited Erdogan's close confidant, Hakan Fidan, the chief of Turkey's Intelligence Service, MIT, to testify in an ongoing investigation on the KCK, allegedly the PKK's urban organization. Fidan refused to appear before the prosecutor and was immediately put under protection by a law passed by the JDP. Six month later, 
in September 2012, Erdogan in an unprecedented move declared his intention to shut down all university-preparation courses. The Cemaat had been running thousands of them across Turkey, which had been a major source of recruitment of high-school students.

Yet, Erdogan had not taken any concrete step for a year and raised the issue once again, but now with more forceful determination. The Cemaat vehemently opposed Erdogan's plan and began to wage its still-lasting opposition to Erdogan. The Cemaat's media dropped its former conciliatory tone and adopted a very hostile one in the succeeding months. More critically, however, the Cemaat-affiliated officers in the Police and the Armed Forces and state prosecutors in the judiciary undertook a series of controversial steps, all in an attempt to implicate Erdogan and his close circle in serious crimes: in the most serious incidence, massive graft investigation launched in December 2013, for example, implicated tens of individuals close to Erdogan in massive corruption and money laundering. In another one, stopping and searching in two separate cases, one in January and the other in June 2014, of lorries that belonged to the National Intelligence Agency implicated Erdogan and his government in sending heavy weapons to Syria, or more specifically, to the Islamic State.

Denying all accusations and blaming international actors and their local collaborators for these operations, Erdogan and his government moved to pacify the Cemaat by reshuffling tens of thousands of police officers and state prosecutors suspected for their ties to the groups and restricted the Cemaat's media outlets, taking out in November 2015 Samanyolu TV and a number of Cemaat-affliated radio stations, Burc FM, from the state-owned satellite.

In a truly watershed event, not only for the relations between the JDP and the Cemaat, but also for the modern history of Turkey, a faction within the Armed Forces attempted a military coup and failed. Erdogan accused Gulen of masterminding the coup and initiated a massive and total purge of the Cemaat both from the state and from the society. In the next two years the government expelled more than 120 thousand employees from the state and shut down hundreds of civil society organizations, including universities, schools and media outlets. Furthermore the government declared the Cemaat as a terrorist organization, as a result of which hundreds of thousands of alleged Cemaat members have been investigated and tens of thousands of them put in jail (Çakır, 2018, July 17).

As these lines are written, the Cemaat seems to be totally defeated in Turkey. Yet, the Cemaat also proved to be able to seriously harm Recep Tayyip Erdogan by tarnishing his international and domestic image. The Cemaat has portrayed Erdogan as someonedeeply sunk into corruption, supporting violent Islamist groups in Syria and elsewhere, unabashedly authoritarian and anti-Western.

Whatever future awaits the Cemaat in Turkey, it is for sure that it helped the JDP truly stage a revolution in Turkey. Having been totally subordinated to the civilian government, the Turkish Armed Forces ceased to be the institution it used to be: the bastion of Kemalism and secularism in Turkey.

\section{NOTES}

\footnotetext{
${ }^{1}$ For some the latter is itself a revolution. Borrowing from Antonio Gramsci, Tugal (2009: 4) calls it "passive revolution" as a result of which "earstwhile radicals and their followers are brought into the fold of neoliberalism, secularism and Western domination."
} 
${ }^{2}$ For the most detailed and recent biographies of Said Nursi, see Canlı and Beysülen (2010) and Cilasun (2018). For a classical work on the topic, see Mardin (1989).

${ }^{3}$ These reforms are well known and well-studied. Two classic works are Lewis (1961) and Berkes (1964).

4 Said Nursi, Yirmiüçüncü Lem'a (Twenty-Third Flash), in his Lem'alar. Available at http://www.risaleinurenstitusu.org/kulliyat. Translation is mine.

5 The major works of Said Nursi in Risale-i Nur Collection consist of Sözler (the Words), Mektubat (the Letters), Lem'alar (the Flashes), Şualar (the Rays), Mesnevi-i Nuriye (the Masnavi of Light), İșarat'ül İ'caz (the Signs of Miraculousness), Asa-y1 Musa (The Staff of Moses), Sikke-i Tasdik-i Gaybi (The Seal of the Affirmation of the Unknown), Muhakemat (Reasonings), İman-Küfür Muvazeneleri (Comparison of Belief and Disbelief), Tarihçe-i Hayat (History of Life- Biography), Emirdağ, Barla and Kastamonu Lahikaları (The Letters of Emirdağ, Barla and Kastamonu), Gençlik Rehberi (Youth Guide). Available at http://www.risaleinurenstitusu.org/kulliyat

${ }^{6}$ Said Nursi discusses these three stages in different treaties of Risale-i Nur. See Alpdoğan (2015).

${ }^{7}$ Written by his devoted disciple Necmettin Şahiner, a book collects not more than 300 memoirs of different individuals with Said Nursi. See Şahiner (2008). Yavuz (2005) reports that the group had only 45 special gathering places acrsoss seven administrative units in Turkey.

${ }^{8}$ Gülen's extreme ascetism is even noted by his critics. See, for example, Veren (2016).

${ }^{9}$ Gülen calls it Hizmet, literally meaning Service. The Muslim Brotherhood's term for the same activity is da'wa literally meaning Calling.

${ }^{10}$ For example, Abdullah Aymaz, Kemalettin Özdemir and Ahmet Özer became teachers while Mehmet Ali Şengül became a prayer leader. To reiterate again, Fethullah Gülen was himself a prayer leader-preacher in Directorate of Religious Affairs.

${ }^{11}$ Three names frequently appear in books on the Cemaat's presence in the Police: Ali Osman Kahya, Mustafa Sağlam and Ramazan Akyürek. There three names studied in the Police High School and Police Academy in the 1970s. It is unclear though whether they became members of the Cemaat before they entered the Police High School. According to Kandira (2001), who wrote the first book on the Cemaat's presence in the Police, Ramazan Akyürek joined the Cemaat after he graduated from the Academy.

${ }^{12}$ Veren (2016: 17-30), who had been in the Cemaat from the 1960s to the 1990 s, claimed that in the 1970s the Cemaat had 12 private students homes. According to his collection the group began to plan a student dormitory in 1972, but could complete in five years.

${ }^{13}$ The fact that during these six years Fethullah Gülen had visited his students serving their mandatory military services is telling in two respects. First, he was not high up in the list of those wanted by the military. Second, his students were young, should in their late teens or early 20s (Veren 2016: 30).

${ }^{14}$ To be emphasized, all religious groups benefitted from the post-1980 coup context. First and foremost the military leaders, who staged the coup, were instrumental in adding a certain dose of religiousity to the state educational system to undermine the appeal of the left in Turkey. For an account of religious revivalism in Turkey, see Yavuz (2006).

${ }^{15}$ The right-wing and left-wing politicians had not been much different in this regard.

${ }^{16}$ In the 1990s at least one report, prepared by Cevdet Saral, was specifically about the Cemaat's presence in the police. An extensive discussion of this report is available in Ş1k (2017).

${ }^{17}$ For a biography of Erdogan, see Pamuk (2001) and Çakır and Calmuk (2001).

${ }^{18}$ The numbers are from the World Bank Quick Data Query at http://www.worldbank.org

${ }^{19}$ The following account can be found in any journalistic account. See, for example, Tayyar (2008), Mavioğlu and Şık (2010, 2011).

${ }^{20}$ For a critical account of the Balyoz case, see Rodrik and Doğan (2010).

${ }^{21}$ Biographical information about the old members of the High Council of Judges and State Prosecutors is available at http://www.danistay.gov.tr and http://www.yargitay.gov.tr They are also available at http://www.hurriyet.com.tr/gundem/16013511_p.asp (accessed on March 9, 2011). 
${ }^{22}$ To cite a few examples, Ismail Aydin was a Judge in Edirne, Bulent Cicekli Professor of Law and Legal Consultant in Ministry of Energy, Ahmet Gokcen Professor of Law, Huseyin Serter a Judge in Adana, Birol Erdem the Director of Personnel in Ministry of Justice, Omer Koroglu a Judge in Rize, Ahmet Kaya was the Director of Educational Center in Turkish Academy of Justice, Rasim Aytin a Lawyer in Ministry of Finance, and Resul Yildirim a Judge in Istanbul Administrative Court. The new members still have predominantly law degrees from Ankara and Istanbul Universities. But, it is also possible to see exceptions: Resul Yildirim, for example, has a degree in Public Finance from Uludag University, Teoman Gokce a Law Degree from Marmara University. Biographical information about the new members of the High Council of Judges and State Prosecutors is available at http://www.hsyk.gov.tr/index.html

\section{REFERENCES}

Berkes, N. 1964. The Development of Secularism in Turkey. Montreal: McGill University Press.

Canl1, C., and Beysülen, Y. K. 2010. Zaman İçinde Bediüzzaman. İstanbul: İletişim Yayınları.

Cilasun, E. 2018. Yeni Paradigmanın Eşiğinde Bediüzzaman Efsanesi ve Said Nursi Gerçeği: Yabancı Arşiv Belgeleriyle. İstanbul: Tekin Yayınevi.

Çakır, F. 2017. 2 yıl süren OHAL'in bilançosu. Habertürk, July 17. URL: https://www.haberturk.com/son-dakika-2-yil-suren-ohal-in-bilancosu-2062195.

Çakır, R., and Çalmuk, F. 2001. Recep Tayyip Erdoğan Bir Dönüşüm Öyküsü. İstanbul: Metis Yayınları.

Doğan, Y. 2013. Gülen-AKP: Rahatsız ilişkiler. Hürriyet, May 20. URL: http://www. hurriyet.com.tr/gulen-akp-rahatsiz-iliskiler-23330451

Göktaş, H. 1987. Askeri Okullarda İkinci Operasyon. Nokta, February 15.

Kandıra, Z. 2001. Cemaatin Copları. İstanbul: Su Yayınları.

Lewis, B. 1961. The Emergence of Modern Turkey. London: Oxford University Press.

Mardin, Ş. 1989. Religion and Social Change in Modern Turkey: The Case of Bediüzzaman Said Nursi Olayl. Albany: State University of New York Press.

Mavioğlu, E., and Şık, A. 2010. Kırk Katır Kırk Satır 2: Ergenekon'da Kim Kimdir? İstanbul: İthaki Yayınları.

Mavioğlu, E., and Şık A. 2011. Kırk Katır Kırk Satır 1: Kontrgerilla ve Ergenekonu. $2^{\text {nd }}$ ed. İstanbul: İthaki Yayınları.

Pamuk, M. 2001. Yasaklı Umut Recep Tayyip Erdoğan. İstanbul: Birey Yayinlari.

Rodrik, D., and Doğan, P. 2010. Balyoz: Bir Darbe Kurgusunun Belgeleri ve Gerçekleri. İstanbul: Destek Yayınları.

Şahiner, N. 2008. Son Şahitler Bediüzzaman Said Nursi'yi Anlattyor. 6 volumes. İstanbul: Yeni Asya Yayınları.

Şık, A. 2017. Imamın Ordusu. İstanbul; Kırmızı Kedi.

Tayyar, Ş. 2008. Operasyon Ergenekon. İstanbul: Timaş Yayınları.

Tugal, C. 2009. Passive Revolution: Absorbing the Islamic Challenge to Capitalism. Stanford: Stanford University Press.

Yavuz, H. 2005. Islamic Political Identity in Turkey. New York: Oxford University Press.

Veren, N. 2016. FETÖ. İstanbul: Destek Yayınları. 